\title{
„Új” Gönczy-glóbuszok Prágából és a Prága melletti Roztokból
}

\author{
MÁRTON Mátyás - TORONYI Bence
}

DOI: $10.30921 / G K .73 .2021 .5 .2$

Absztrakt: Jelen tanulmány egy három cikkbốl álló sorozat második tagja, amelyben a szerzök bemutatják a 2017 óta látókörükbe került új - a szakirodalomban ismeretlen - glóbuszokat, amelyek magyar nyelvú változatát Gönczy Pál szerkesztette.

A szerzók részletekbe menöen mutatnak be egy $15,8 \mathrm{~cm}$ és két $21,7 \mathrm{~cm}$ átméröjü, Gönczy magyaritotta és a Prága melletti Roztokban (ma Roztoky) a Felkl és fia cég által kiadott glóbuszt. Ismertetik a 31,6 cm átmérôjjú prágai Felklglóbusz elsố kiadását, valamint ennek átvizsgált második kiadását a Prága melletti Roztokból a Felkl és fia cégtól. Bemutatnak egy nem túl régen restaurált 47,4 cm átmérôjü Felkl-Gönczy-glóbuszt is, amelynek restaurálása meglepetéssel szolgált.

Abstract: This paper is the second one in a series of three articles in which the authors present the new globes that have come to their attention since 2017 and are unknown in the literature. Their Hungarian version was edited by Pál Gönczy.

The authors present in detail a globe of $15.8 \mathrm{~cm}$ and two globes of $21.7 \mathrm{~cm}$ in diameter translated into Hungarian by Gönczy and published by Felkl and his son in Roztok near Prague (today Roztoky). The first edition of the $31.8 \mathrm{~cm}$ diameter Felkl globe in Prague and its revised second edition from Roztok near Prague from Felkl and his son are described. They also present a recently restored $47.4 \mathrm{~cm}$ diameter Felkl-Gönczy globe, the restoration of which brought some surprise.

Kulcsszavak: magyar nyelvú glóbuszok; glóbuszgyártó múhelyek: Jan Felkl Prágában, Felkl és fia Roztokban Prága mellett; Virtuális Glóbuszok Múzeuma (VGM)

Keywords: Hungarian-language globes; globe making factories: Jan Felkl in Prague, Jan Felkl \& Son in Roztok near Prague; Virtual Globes Museum (VGM)

\section{Bevezetés}

Plihál Katalin 2016-ban megjelent, nyomtatott magyar nyelvú föld- és éggömbökkel foglalkozó nagy összefoglaló munkáját követốen „sem állt le az élet”. Újra meg újra elôkerülnek ezen érzékeny mútárgyaknak „túlélô" darabjai, s egy-egy glóbusz olyan kiadásaival, olyan példányaival találkozhatunk, amelyeket korábban nem ismertünk, vagy létezésüket csak feltételezhettük.

Biztosan tudjuk, hogy Gönczy elsố Felkl-földgömbjének magyarítása 1870-ben történt: „Földgömb magyar nyelven. Kiadja Felkl, Prágában. 1870." (MTA Alm. 1892, p. 137). Figyeljük meg, hogy egy (!) glóbuszról van szó! Ugyanebben a bibliográfiai összeállításban „Schotte sima és domború földgömbjei különféle átmérôkkel. Berlin, 1872." szerepel. Ugyanezt az egyesés többesszámbeli megkülönböztetést találjuk a Szinnyei-féle (1894, pp. 1364-1365) Göczy-bibliográfiában! (Meg kell jegyezni, hogy a két bibliográfia nem azonos. Témánk szempontjából is vannak különbségek, például Szinnyeinél szerepel a „Tellurium Planetarium. Berlin, 1872." a felsorolt múvek között, míg az Almanachban nem.

Elgondolkodtató az is, hogy Gönczy a Felkl, illetve a Felkl és fia cégek négy különbözô átmérôjuu földgömbjét jegyzi a kolofonok szerint (amelyeket a magyar királyi közoktatási miniszter megrendelése alapján készíttetett), ugyanakkor a magyar szakirodalom három, a minisztérium által támogatott földgömbrôl tud. Ezek a 21,7, a 31,6 és a 47,4 cm-esek (a 15,8 cm átmérójúek nem szerepelnek ezek között!).

Széles körben ismert ma már az is, hogy egyes Felkl-Hunfalvyföldgömbök kiadása akár több évvel is megelôzi az 1870-es idốpontot (Márton 2010a, 2010b; 2011). Biztosan közös munkát tôlük azonban csak 1881-bôl ismerünk: „Schneider természetrajzi képes átlásza, fordították Hunfalvy János és Gönczy Pál. 1881." (MTA Alm. p. 137).

Máig senki nem vizsgálta viszont, hogy vajon mutatnak-e rokonságot az idôben párhuzamosan vagy közel egy idôben megjelent Hunfalvy- és Gönczy-földgömbmagyarítások? A továbbiakban erre a kérdésre is keressük a választ, ahol lehetôség kínálkozik rá. A glóbuszok magyarított névrajzában a két szerzố megkülönböztetésére (amennyiben nevük a glóbuszokon nem szerepel) szinte biztos azonosítónak tekintik a térképtörténészek, hogy Hunfalvy „világ tenger”-nek nevezi Gönczy „óczeán”-jait, valamint hogy a tengeráramlásokat Hunfalvy „ömlés”-ként, míg Gönczy folyás"-ként emlegeti. Az elsô állítás „sántít” kicsit [ahogy ezt Szabó (2010) összehasonlító névgyứjtéseit vizsgálva megállapíthatjuk], mert a berlini Schotte-glóbuszokra ez nem áll, ott Gönczy egyszerúen „tengert” használ. A másik állítás is inkább csak a prágai és roztoki Felkl-gömbökre igaz, de egyes Gönczy-földgömbökön már az itt kiadott (pl. 15,8 cm-es) glóbuszokon is az „áramlás” vagy „áramlat” megírás szerepel. Ezek a „felismerések” tehát nem tekinthetôk „perdöntônek” a magyarítás szerzőségét illetôen. 
Anélkül, hogy a részletekben elmélyednénk, nyugodtan kijelenthetjük, hogy az azonos kolofonszöveg nem feltétlenül jelent azonos földgömbtérképi tartalmat! Tehát ahhoz, hogy a különbözô kiadásokat, a különbözô változatokat feltárhassuk, minden esetben alaposan meg kell vizsgálni az egyes térképi elemeket (határrajz, domborzat, névrajz stb.) mind tartalmi, mind ábrázolás-módszertani szempontból. A figyelmes olvasó több példát talál ilyen eltérésekre cikkünkben is (lásd a 21,7 cm-es vagy a 47,4 cm-es glóbuszváltozatokat). Az ilyen változatok keletkezésének oka lehet például az, hogy egy adott gömb kasírozásakor csak egyes felújított gömbszegmenseket vagy új pólussapkát használtak, „cseréltek” le a korábbiakhoz viszonyítva. Nem egyedülálló megoldás ez, hiszen a II. világháborút követô magyar glóbuszkészítés is ismerte a „felülragasztást” - például a kolofonok „cseréjére” vagy a politikai változások ábrázolásának „érdekében”. Ismerünk napjainkban is olyan atlaszkiadói megoldást, hogy a lapokra felvágott és így tárolt kiadványnak például csak az új autópálya-szakasz átadása miatt bekövetkezett jelentős változást „elszenvedett” lapját nyomják ki, és a továbbiakban az így elóállt új atlaszt kötik be és forgalmazzák.

\section{Korábban ismeretlen 15,8 cm-es Felk1-Gönczy- glóbusz az érdi Magyar Földrajzi Múzeumban}

Dr. Kubassek János múzeumigazgató és Puskás Katalin restaurátor, gyújteménykezelố szívességébool kaptuk meg azt a megtiszteló lehetôséget, hogy az érdi Magyar Földrajzi Múzeum (MFM) egyik újabb kincsének ismertetését közzétegyük. A „kincs” egyáltalán nem túlzó megnevezése ennek a glóbusznak, hiszen az ilyen átmérôjú Gönczy által magyarított Felkl-glóbuszok közül eddig ismeretlen „évjáratúról” és tartalmúról van szó! „Rokona” az egyetlen korábbról ismert Gönczy által magyarított 15,8 cm átmérôjű, 1905 körül kiadott országhatárbandos, lejtôcsíkozásos domborzatrajzú politikai-domborzati földgömbnek (VGM ID 47), amelyen azonban már nem szerepel, hogy „a m. kir. közoktatási | minister megrendeléseböl (!)” készült volna.

$15,8 \mathrm{~cm}$ (6 bécsi hüvelyk) átmérójú, 1 : 81000000 méretarányú domborzati-politikai földgömb. Egyenlitối kerülete: $49,62 \mathrm{~cm}$.

Kontinens- és egyes területeken országhatárbandos, elnagyolt lejtôcsíkozásos domborzatrajzú, 1884 után kiadott glóbusz, párhuzamos vonalfonatokkal jelölt tengeráramlásokkal és nyilakkal jelölt áramlásirányokkal, tengermélységadatokkal. A kezdőmeridián greenwichi, a hoszszúság mérése innen indul K. és Ny. irányban $10^{\circ}$-os megírással. Jó állásban megrajzolt Ekliptika (égi egyenlítô) jellemzi. A kolofon: „FÖLDGÖMB | a legújabb felfedezések nyoman (!) | Magvarúl (!) szerkesztette | Gönczy Pál | a m. kir. közoktatási | minister megrendeléseböl. (!) | Kiadta | Felkl J. és fia" (VGM ID 144).

A földgömb átfedôsávval bôvített $30^{\circ}$-os, papírra nyomtatott gömbszegmensek hordozógömbre kasírozásával készült, 12 db - sarkokig nyúló gömbszegmensből áll, pólussapkák nélkül. A hordozógömb anyaga valószínúleg papírmasé, amelynek felületi egyenetlenségeit vékony gipszréteg felhordásával simították.

Egyszerú (ún. I. számú) felszerelésû: azaz feketére lakkozott, esztergált faállványba illesztett, hajlított acélhuzal tartja a gömböt, amelynek tengelyrésze a vízszintessel $66,5^{\circ}$-ot zár be. Magassága: $32 \mathrm{~cm}$.

Ismeretlen (nem jelölt) évszámú kiadás hordozógömbre kasírozott, állványra szerelt példánya. Az érdi Magyar Földrajzi Múzeum gyújteményébe Schreiber Károlyné ajándékaként került 2017. szeptember 5-én. Jelzete: 2017.3.1. A glóbusz legkorábban 1884-ben vagy az után készülhetett. E mellett szól a greenwichi kezdőmeridián, mivel csak az 1884. évi washingtoni nemzetközi meridiánegyezmény mondja ki, hogy a földrajzi hosszúság számozásának kiinduló délköre a greenwichi passzázsmúszeren áthaladó délkör. A magyar nyelvú kiadás szerkesztője Gönczy Pál volt.

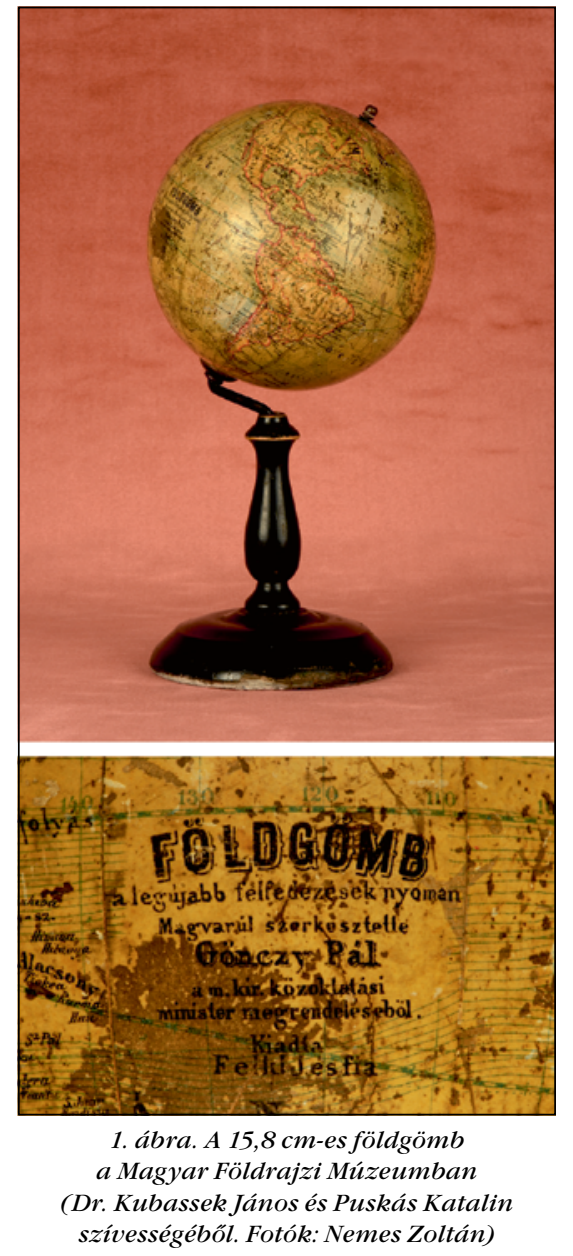

A glóbusz térképi tartalmának jellemzói

- A vetület: valószínúsíthetôen meridiánokban és Egyenlítőben hossztartó hengervetület („négyzetes hengervetület") transzverzális elhelyezésú változata a $30^{\circ}$-os gömbszegmensek elkészítéséhez.

- Greenwichi kezdômeridián.

- A szélességi és hosszúsági irányokban egyaránt $10^{\circ}$-os beosztású, a sarkokig terjedố fokhálózat $12 \mathrm{db}$ $30^{\circ}$-os gömbszegmensre osztott. A kezdômeridián és az Egyenlítô $1^{\circ}$-os „létrás” ábrázolással kiemelt az egyébként folyamatos vonallal megrajzolt $10^{\circ}$-os fokhálózatból. A térítôk és a sarkkörök szaggatott vonallal ábrázoltak. Az Ekliptika ugyancsak „létrás” ábrázolással kiemelt.

- A kontinensek és a jelentôsebb szigetek partvonalán túl a vízrajz a nagyobb folyókat és ezek fôbb mellékfolyóit, valamint (mélységábrázolás nélkül) a legjelentősebb tavakat tartalmazza. 
- A szárazföldi területek okker színezésúek, kontinenshatárbanddal. Barna színú lejtôcsíkozásos domborzatrajzzal egészül ki a szárazföld-ábrázolás.

- A szárazföldi területeken szaggatott vonallal (Európában) vagy a kontinenshatárband színével egyezố vékony határbanddal rajzolt országhatárok.

- A településábrázolás nem kategorizált, a településjelek üres kék körök (gyakran hiányoznak!). A fóvárosok és a legjelentősebb települések szerepelnek csupán.

- A tengerek mélységábrázolás nélküliek (néhány mélységpontérték megadásával, pl. a „Kurili-szig.”-tôl DK-re: 8512 m. - nyilván a mélytengeri árok akkor ismert mélysége). Alapszínük világoskék lehetett, amely azonban a lakkréteg besárgulása miatt inkább sárgás árnyalatúnak látszik.

- A tengeráramlások sávjait sötétkék színú vonalkötegek mutatják, irányukat nyilak jelzik, esetenként névvel megírtak (Japáni-aramlas, Déli egyenlitöi folyás, Déli sarkvidéki áramlás, Horn foki áramlat, Paszát áramlás).

- A teljes névrajz magyaros írást követ, illetve erre törekvô, a litográfus azonban vélhetốn nem magyar anyanyelvú. Erre az ékezetes betûk gyakran pontatlan kezeléséból következtethetünk (Michigan tö, Erie-tö). „Modern” névrajzú a földgömb, mint azt az alábbi példák is mutatják.

- A vízrajzi nevek a ma alkalmazott jobbra dôlô kurzív írással szemben balra dôlnek: óceánok (NAGY v. CSENDES-ÓCZEÁN, INDIAI-ÓCZEÁN, ÉSZAKI JEGES TENGER; DÉLI JEGES TENGER), tengerek (Karibitenger; Északi-tngr.; Feketetengr.; Vörös-tenger), tengeröblök (Mexicoi-öböl; Hudson-öb.), tengerszorosok (Davis-szor, Mozambiki-szor.), vízfolyások (Missziszippi; Miszuri; Amazonfoly.) és a tavak (Aral-tó., Nyassa t.) nevei.

- Hasonlóan magyaros a szigetcsoportnevek [Hawaii-sz. (Sandvich sz.); Azor-sz.; Verde-fok-szig.;
Amirante-sz.] és a szigetnevek (Elefant sz. - Déli-Shetland), valamint a földfokok neveinek (Jóremenyseg f.) írásmódja.

- A kontinensek nincsenek megírva. A szárazföldi névrajz elemei között megtaláljuk az országneveket (Egyesült Államok; Brit-Amerika = Kanada; Franczia or.; Spanyolhon; Orosz Birodalom); a településneveket (Stokholm, Madrid, Paris, Odessza, Sztambul, Tobolszk); nagytájneveket (Szahara, Szudan, Sziberia, Gobi-sivatag v. Samo, Eló India, Hatso India).

- A glóbusz Kelet-Közép-Európát ábrázoló részén szerepel Austria és Magyarország megírása. Az utóbbiból sérülés miatt csak a „Ma” olvasható. Ettôl dél-délkeletre kezdôdik „Törökorsz” neve. A Kárpát-térség és szúk környezete területén még az alábbi neveket vélhetjük felfedezni: Bécs, Buda, Pest (meg kell itt jegyezni, hogy Budapest már 1873-ban létrejött), Adriai-t., Duna, Bukar[est], Balkan. Érdekesek a „Közép Amerika" (mint nagytáj) és az "AUSZTRALIA" (mint az egyetlen megnevezett "kontinens" - a Brit Birodalomhoz tartozó országok nevei nem nagybetúsek -, valamint a „Rák-téritô” és a „Bak téritö” megírások. Az „Északi Sarkkör"-t és a „Déli sarkkör"-t is megírták, az „Ejszaki Sark” kétszer is megírt, viszont a Déli-sark megírása nem szerepel.

- A nyomtatáshoz felhasznált színek száma nyolc: fekete, sötétkék, világoskék, világosokker, élénksárga, barna, élénkvörös és téglavörös.

- Fekete: a teljes névrajz, kivéve a fokszámokat és a mélységszámokat.

- Sötétkék: a fokhálózat és a fokszámok, az Ekliptika, a partvonal, a vízrajz (vízfolyások, tókontúrok és felületsraffozásuk), a tengeráramlásrajz, az áramlásnyilak és a mélységszámok, valamint az országhatárrajz (egy része) és a településkarikák.

- Világoskék: a tengerfelületek.

- Világosokker: a szárazföldek felületi színezése.
- Élénksárga: Európa és Afrika (?), valamint (téglavörössel együtt nyomott, narancsszínú): Ausztrália, Óceánia és az Antarktika Ausztrália felé esố ismert partszakaszainak kontinenshatárbandja.

- Barna: a lejtốcsíkozásos domborzatábrázolás.

- Élénkvörös: Ázsia kontinenshatárbandja.

- Téglavörös: Amerika és az Antarktika Dél-Amerika felé esô, valamint (élénksárgával együtt nyomott, narancsszínú): Ausztrália, Óceánia és az Antarktika Ausztrália felé esô ismert partszakaszainak kontinenshatárbandja.

\section{Korábban nem ismert}

21,7 cm-es Felk1-Gönczyglóbusz Nován a Göcseji Múzeum gyújteményébó1

Ma a novai Plánder Ferenc Helytörténeti Gyújtemény állandó kiállításán bemutatott, a zalaegerszegi Göcseji Múzeum állományába tartozó glóbusz nagy felbontású fényképfelvételeihez Megyeri Anna közremúködésével, Horváth Nikolett szívességéből jutottunk hozzá. A felvételeket Simon Balázs készítette. Ez szolgált alapul és tette lehetôvé számunkra az eddig a magyar szakirodalomban le nem írt földgömb részletes ismertetését.

„Rokona” az 1903-as kiadású glóbusznak (VGM ID 106), tartalmuk nagyrészt megegyezik, de a transzszibériai vasútvonal nincs jelölve. Érdekes, hogy az 1903-as kolofonja is más: „A FÖLD” helyett „FÖLDGÖMB” megírás áll, és nem szerepel a „Rozstok, Pragam” kiadói hely megadása sem.

Ez a glóbusz is legkorábban 1903 ban vagy az után készülhetett. E mellett szól, hogy Orenje és Transvaal 1903-ban elveszti függetlenségét (a búr háború vége) és „Brit-Fönhatóság”ként kerül ábrázolásra ez a terület Afrikában.

Megkülönböztetô jellegzetessége a földgömbnek, hogy a Földközi-tenger és környezetének nevei jó része északi irányba elcsúszott. Figyeljük meg pl. a Sztambul, Tunis vagy a Tripoli megírásokat (2. ábra)! 


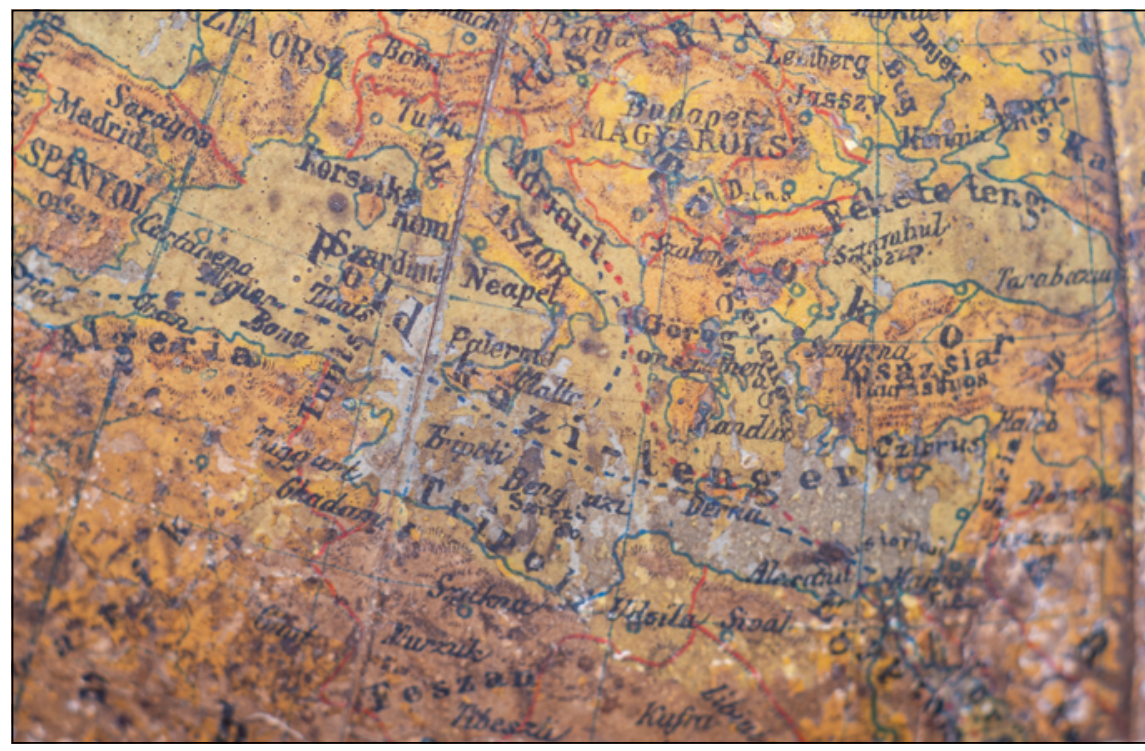

2. ábra. A névrajzi elemek elcsúszása a Földközi-tenger vidékén

$21,7 \mathrm{~cm}\left(8^{1 / 4}\right.$ bécsi hüvelyk) átmérójú, $1: 58733000$ méretarányú politikai-domborzati földgömb. Egyenlítói kerülete: $68,23 \mathrm{~cm}$.

Országhatárbandos, lejtőcsíkozásos domborzatrajzú, 1903-ban vagy közvetlenül az után kiadott glóbusz, párhuzamos vonalfonatokkal jelölt tengeráramlás-ábrázolással, áramlásnevekkel, nyilakkal jelölt áramlásirányokkal, tengermélységadatokkal, hajózási útvonalakkal és transzkontinentális vasútvonalakkal. A kezdômeridián greenwichi, jó állásban megrajzolt Ekliptika jellemzi. A kolofon: „A FÖLD | a legújabb felfedezések nyomán | Magvarúl (!) szerkesztette | Gönczy Pál | a m. kir. közoktatási minister megrendeléseböl (!). | Kiadta | Felkl J.és fia | Rozstok,Pragam ${ }^{1}$ (!)".

A földgömb átfedósávval bôvített $30^{\circ}$-os, papírra nyomtatott gömbszegmensek hordozógömbre kasírozásával készült, $12 \mathrm{db}$ - sarkokig nyúló gömbszegmensbôl áll, pólussapkákkal. A hordozógömb anyaga valószínúleg papírmasé, amelynek felületi egyenetlenségeit vékony gipszréteg felhordásával simították.

Egyszerú (ún. I. számú) felszerelésú: azaz feketére lakkozott, esztergált faállványba illesztett, hajlított acélhuzal tartja a gömböt, amelynek tengelyrésze a vízszintessel $66,5^{\circ}$-ot zár be. Magassága: $44 \mathrm{~cm}$.

\footnotetext{
A kiadás helyeként megadott Rozstok gyakran Roztok alakban szerepel (ma Roztoky). Pragam = Prága mellett. Egyes glóbuszokon helyesen: Prága m. vagy Prága mellett megírásként találjuk.
}

\section{A glóbusz térképi} tartalmának jellemzôi

- A vetület: valószínúsíthetôen meridiánokban és Egyenlítőben hossztartó hengervetület („négyzetes hengervetület") transzverzális elhelyezésú változata a $30^{\circ}$-os gömbszegmensek elkészítéséhez.

- Greenwichi kezdômeridián.

- A szélességi és hosszúsági irányokban egyaránt $10^{\circ}$-os beosztású, sarkokig terjedő fokhálózat $12 \mathrm{db}$ $30^{\circ}$-os gömbszegmensre osztott. A kezdômeridián és az Egyenlítô $1^{\circ}$-os „létrás” ábrázolással kiemelt az egyébként folyamatos vonallal megrajzolt $10^{\circ}$-os fokhálózatból. A térítók és a sarkkörök szaggatott vonallal ábrázoltak. Az Ekliptika ugyancsak „létrás” ábrázolással kiemelt.

- A kontinensek és a jelentősebb szigetek partvonalán túl a vízrajz a nagyobb folyókat és ezek fóbb mellékfolyóit, valamint (mélységábrázolás nélkül) a legjelentôsebb tavakat tartalmazza.

- A szárazföldi területek fehérek lehettek (a lakkréteg elszínezôdése miatt sárgás tónusúak), országhatárbanddal. Barna színú lejtôcsíkozásos domborzatrajzzal egészül ki a szárazföld-ábrázolás.

- A településábrázolás nem kategorizált, a településjelek üres kék körök (a településnevek vagy a kék körök esetenként hiányoznak!). A fóvárosok és a legjelentősebb települések szerepelnek csupán (gyakran

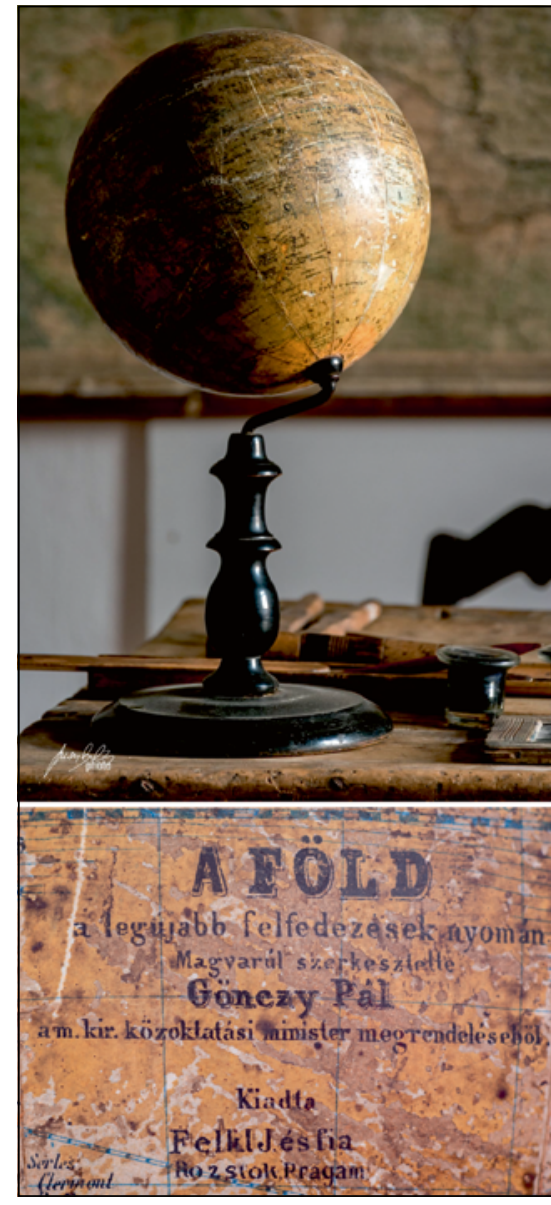

3. ábra. A 21,7 cm-es földgömb a novai Plánder Ferenc Helytörténeti Gyújteményben (Megyeri Anna közremüködésével Horváth Nikolett szivességébôl. Fotók: Simon Balázs)

rövidítve: Kopenh., Brussz., Strasb., Hambg., Münch.).

- A tengerek alapszíne világoskék, mélységábrázolás nélküliek (néhány mélységpontérték megadásával, pl. a „Kurili-szig.”-tôl DK-re: 8512 m. - nyilván a mélytengeri árok akkor ismert mélysége), vagy DK-re az „INDIAI-” megírás mellett: $4500 \mathrm{~m}$.

- A tengeráramlások sávjait sötétkék színú vonalkötegek mutatják, irányukat nyilak jelzik, általában névvel megírtak (Golf-áramlas, A csendes-tenger ész. áramlas (!), Japáni-áramlas, Egyenlitôi déli folyás, Délsarki folyo-áramlát (!), Horn foki áramlat, Passzat (!) áramlas (!) stb.).

- A teljes névrajz magyaros írást követ, illetve erre törekvő, a litográfus azonban vélhetôen nem magyar anyanyelvú. Erre az ékezetes betűk gyakran pontatlan kezeléséból is következtethetünk (lásd fentebb a tengeráramlások megnevezéseit). 
„Modern” névrajzú a földgömb, mint azt az alábbi példák is mutatják.

- A vízrajzi nevek a ma alkalmazott jobbra dôlô (kurzív) írással szemben balra dőlnek: óceánok (NAGY v. CSENDES-ÓCZEÁN, INDIAI-ÓCZEÁN, ÉSZAKI JEG[...] TENGER; DELI JEGESTENGER), tengerek (ARABTENGER， JAPÁNI-TENGER; KELET-KHINAI-T.; DÉLI-KHINAITENGER; Sárga-t., Szului-t., Fekete-teng.; Földközi-tenger), tengeröblök (MEXIKÓI-ÖBÖL; HUDSON-ÖBÖL.; Guineai-öb.), tengerszorosok (Davis-szor, Mozambiki-t-szoros), vízfolyások (Lorincz, Misszisippi; Miszuri) és a tavak (Felso tó, Huron tó, Aralöb. (!!!), Nyassza) nevei.

- Hasonlóan magyaros a szigetcsoportnevek (Szunda Szigetek; Filippini-szig.; Hawaii-sz. cs., Sandwich-sz.; Azóri-Sz.; Verde-fok (!!!); Komori-sz., Déli-Shetland-sz.), valamint a földfokok neveinek (Joremenyseg f.) írásmódja. A szigetek nevében általában nem szerepel a „sziget” földrajzi köznév (Havaji (!), Sz Ilona).

- A kontinensek nincsenek megírva. A szárazföldi névrajz elemei között megtaláljuk az ország- és tartományneveket (Egyesült Államok; Britországi Észak Amerika = Kanada; FRANCZIA ORSZ; SPANYOL orsZ; DÁNORSZ; NÉMETORSZ; OROSZ BIRODALOM, NémetKelet-Afrika, Új-Dél-Wales, Nyugati Ausztrália); a településneveket (Stokholm, Madrid, Paris, Sztambul, Tobolszk, Krasznojarszk, Irkutszk); nagytájneveket (Szahara, SZUDAN, SZIBERIA， BELSÔ ÁZSIA, Gobi-sivatag sin Samo azaz homoktenger, ELO INDIA, HATSO INDIA).

- A glóbusz Kelet-Közép-Európát ábrázoló részén szerepel AUSTRIA és MAGYARORSZ megírása. Ettől dél-délkeletre kezdődik „Törokorsz” neve, a felirat elsô két betûje még Magyarország területén. A Kárpát-térség és szűk környezete területén még az alábbi neveket vélhetjük felfedezni: Praga, Budapest, Adriai-t., Duna, Lemberg, Jasszv = Jászvásár.

- A földgömbön nagy számban szerepelnek népnevek, pl. Tuarik, Hottentottok, Jakutok, Tunguzok, Karjakok, Kirgizek.

- Érdekesek a „KÖZÉP AMERIKA” (mint nagytáj) és az „AUSZTRALIA” (mint az egyetlen megnevezett „kontinens” - a Brit Birodalomhoz tartozó országok nevei nem nagybetûsek -, valamint az „Egyenlitö”, a „Rak téritő” és a „Bak téritö” megírások. Az „Északi sarkkor”-t és a „Déli- Sarkkör"-t is megírták, az „ÉSZAKI SARK” és a „DÉLI SARK” is megírt.

- A nyomtatáshoz felhasznált színek száma pontosan nem határozható meg (de a hasonló kiadások alapján valószínúleg ez nyolc: fekete, sötétkék, világoskék, élénksárga, barna, élénkvörös, téglavörös és zöld.

- Fekete: a teljes névrajz, kivéve a fokszámokat és a mélységszámokat.

- Sötétkék: a fokhálózat, valamint a fok- és mélységszámok, az Ekliptika, a partvonal, a vízrajz (vízfolyások, tókontúrok és felületsraffozásuk), a tengeráramlásrajz, az áramlásnyilak, valamint az országhatárrajz (egy része) és a településkarikák.

- Világoskék: a tengerfelületek.

- Élénksárga: az országhatárrajz egy része (?).

- Barna: a lejtốcsíkozásos domborzatábrázolás.

- Élénkvörös: az országhatárrajz egy része (?).

- Téglavörös: az országhatárrajz egy része.

- Zöld: az országhatárrajz egy része (?)

\section{Korábban ismeretlen 21,7 cm-es Felk1-Gönczy- glóbusz Toronyi Bence gyújteményében}

Kitûnô állapotban fennmaradt példány, melynek szépségét Lente Zsuzsanna 2019-ben végzett, hozzáértô restaurátori munkája csak emelte, olyannyira, hogy úgy megújult, mintha most került volna ki a roztoki múhelyből.
A „rokonságba” sorolható, tartalmilag nagyrészt megegyezó 1903as kiadású (VGM ID 106) glóbusz kolofonja más: „A FÖLD” helyett „FÖLDGÖMB” megírás áll, és nem szerepel a „Rozstok,Pragam” kiadói hely megadása sem. Perdöntô lehet a transzszibériai vasútvonal Bajkálparti vizsgálata is, mivel a tavat nyugatról megkerüló szakasz csak 1904ben készült el, és 1905-ben adták át a forgalomnak.

Az ugyancsak „rokonnak” tekinthetô 1905-ös verzión (VGM ID 101) már a Mandzsúriát átszelố szakaszt is ábrázolták.

Az itt tárgyalt glóbusz tehát szintén 1905-ös kiadású lehet, de a VGM ID 101 azonosítójú glóbusznál korábbi, mivel a Bajkált megkerülő vasúti szakasz már szerepel rajta, de a mandzsúriai nem.

$21,7 \mathrm{~cm}$ (81/4 bécsi hüvelyk) átmérójú, 1 : 58733000 méretarányú politikai-domborzati földgömb. Egyenlitối kerülete: $68,23 \mathrm{~cm}$.

Országhatárbandos, lejtôcsíkozásos domborzatrajzú, 1905-ben vagy az után kiadott glóbusz, párhuzamos vonalfonatokkal jelölt tengeráramlás-ábrázolással, áramlásnevekkel, nyilakkal jelölt áramlásirányokkal, tengermélységadatokkal, hajózási útvonalakkal és transzkontinentális vasútvonalakkal. A kezdốmeridián greenwichi, jó állásban megrajzolt Ekliptika jellemzi. Kolofon: „A FÖLD | a legújabb felfedezések nyomán | Magvarúl (!) szerkesztette | Gönczy Pál | a m. kir. közoktatási minister megrendeléseböl (!). | Kiadta | Felkl J.és fia | Rozstok,Pragam (!)" (VGMfeldolgozása készül).

A földgömb átfedôsávval bôvített $30^{\circ}$-os, papírra nyomtatott gömbszegmensek hordozógömbre kasírozásával készült, $12 \mathrm{db}$ - sarkokig nyúló - gömbszegmensbôl áll, pólussapkákkal. A hordozógömb anyaga valószínúleg papírmasé, amelynek felületi egyenetlenségeit vékony gipszréteg felhordásával simították.

Egyszerú (ún. I. számú) felszerelésú: azaz feketére lakkozott, esztergált faállványba illesztett, hajlított acélhuzal - amelynek tengelyrésze a vízszintessel $66,5^{\circ}$-ot zár be - tartja a gömböt. Magassága: $44 \mathrm{~cm}$. 


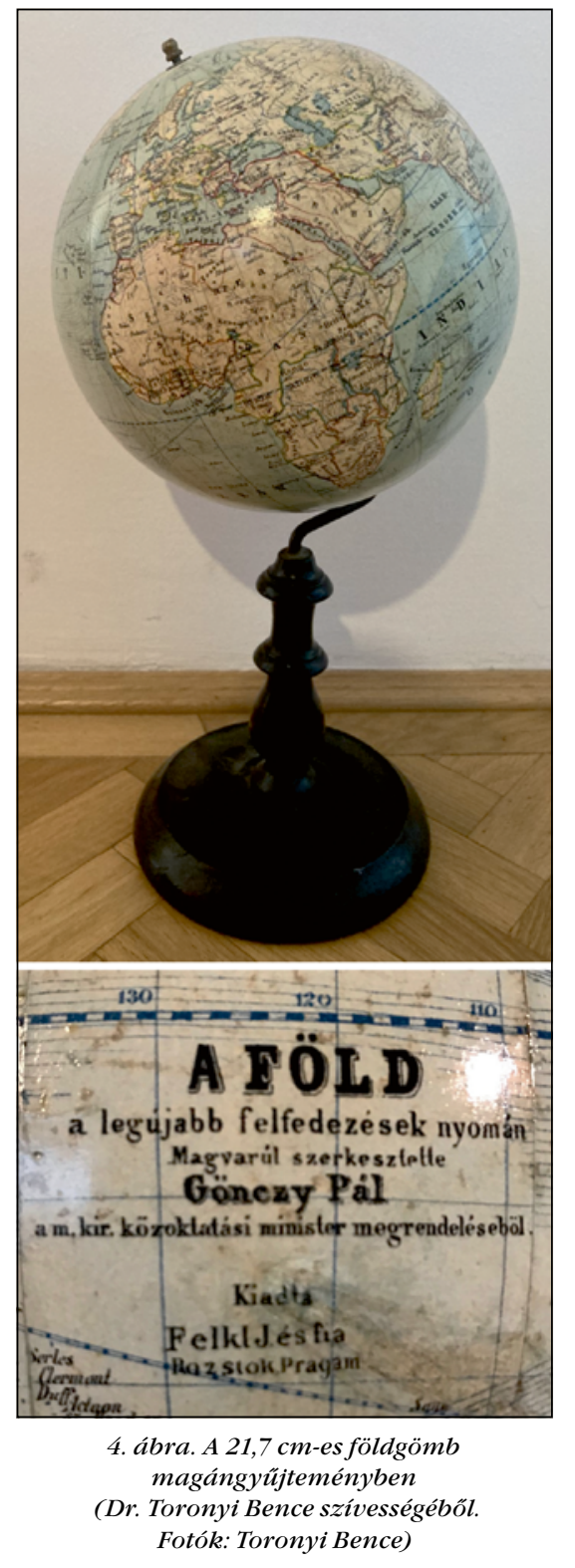

\section{A glóbusz térképi} tartalmának jellemzói

- A vetület: valószínúsíthetően meridiánokban és Egyenlítôben hossztartó hengervetület („négyzetes hengervetület") transzverzális elhelyezésú változata a $30^{\circ}$-os gömbszegmensek elkészítéséhez.

- Greenwichi kezdőmeridián.

- A szélességi és hosszúsági irányokban egyaránt $10^{\circ}$-os beosztású, sarkokig terjedố fokhálózat $12 \mathrm{db}$ $30^{\circ}$-os gömbszegmensre osztott. A kezdốmeridián és az Egyenlítô $1^{\circ}$-os „létrás” ábrázolással kiemelt az egyébként folyamatos vonallal megrajzolt $10^{\circ}$-os fokhálózatból. A térítők és a sarkkörök szaggatott vonallal ábrázoltak. Az Ekliptika ugyancsak „létrás” ábrázolással kiemelt.
- A kontinensek és a jelentôsebb szigetek partvonalán túl a vízrajz a nagyobb folyókat és ezek fôbb mellékfolyóit, valamint (mélységábrázolás nélkül) a legjelentôsebb tavakat tartalmazza.

- A szárazföldi területek fehérek, országhatárbanddal. Barna színú lejtốcsíkozásos domborzatrajzzal egészül ki a szárazföld-ábrázolás.

- A településábrázolás nem kategorizált, a településjelek üres kék körök (a településnevek vagy a kék körök gyakran hiányoznak!). A fóvárosok és a legjelentôsebb települések szerepelnek csupán.

- A tengerek mélységábrázolás nélküliek (néhány mélységpontérték megadásával, pl. a „Kurili-szig.”-tôl DK-re: 8512 m. - nyilván a mélytengeri árok akkor ismert mélysége). Alapszínük világoskék.

- A tengeráramlások sávjait sötétkék színú vonalkötegek mutatják, irányukat nyilak jelzik, általában névvel megírtak (Japániáramlas, Egyenlitối déli folyá (!) (A VGM ID 106-on még szerepel az „s” betú), Délisarki folyoáramlát (!), Horn foki áramlat, Passzat (!) áramlas (!) stb.).

- A teljes névrajz magyaros írást követ, illetve erre törekvő, a litográfus azonban vélhetóen nem magyar anyanyelvú. Erre az ékezetes betûk gyakran pontatlan kezelésébôl következtethetünk (Michigan tö, és lásd fentebb a tengeráramlások megnevezéseit is). „Modern” névrajzú a földgömb, mint azt az alábbi példák is mutatják.

- A vízrajzi nevek a ma alkalmazott jobbra dôlố kurzív írással szemben balra dőlnek: óceánok (NAGY v. CSENDES-ÓCZEÁN, INDIAI-ÓCZEÁN ÉSZAKIJEGES TENGER; DÉLI JEGES-TENGER), tengerek (KARIBI-TENGER; Fekete-teng.; Vörös-tenger), tengeröblök (MEXIKÓI-ÖBÖL; HUDSON-ÖBÖL.), tengerszorosok (Davis-szor, Mozambiki-t-szoros), vízfolyások (Missziszippi; Miszuri) és a tavak (Aralöb., Nyassza) nevei.

- Hasonlóan magyaros a szigetcsoportnevek [Havaji-sz.
(Sandwich-sz.); Azóri-Sz.; Verdefok; Amirante-sz.] és a szigetnevek (Elefant sz. - Déli-Shetland-sz), valamint a földfokok neveinek (Joremenyseg f.) írásmódja.

- A kontinensek nincsenek megírva. A szárazföldi névrajz elemei között megtaláljuk az országneveket (Egyesült Államok; Britországi Észak Amerika = Kanada; FRANCZIA ORSZ.; SPANYOL ORSZ.; NÉMET ORSZ.; OROSZ BIRODALOM); a településneveket (Stokholm, Madrid, Paris, Sztambul, Tobolszk); nagytájneveket (Szahara, SZUDAN, SZIBERIA, Gobi-sivatag sin Samo azaz homoktenger, ELO INDIA, HATSO INDIA).

- A glóbusz Kelet-Közép-Európát ábrázoló részén szerepel AUSTRIA és MAGYARORSZ. megírása. Ettôl dél-délkeletre kezdôdik „Törökorsz” neve, a felirat elsô két betűje még Magyarország területén. A Kárpát-térség és szúk környezete területén még az alábbi neveket vélhetjük felfedezni: Praga, Budapest, Adriai-t., Duna, Lemberg, Münch (en). Érdekesek a „KÖZÉP AMERIKA" (mint nagytáj) és az "AUSZTRALIA" (mint az egyetlen megnevezett "kontinens” - a Brit Birodalomhoz tartozó országok nevei nem nagybetúsek -, valamint a „Rak téritô” és a „Bak téritö” megírások. Az „Északi sarkkor"-t és a „Déli- Sarkkör"-t is megírták, az „ESZAKI SARK” is megírt, viszont a Déli-sark megírása helyett a "SARK” megírás szerepel kétszer is.

- A nyomtatáshoz felhasznált színek száma nyolc: fekete, sötétkék, világoskék, élénksárga, barna, élénkvörös, téglavörös és zöld.

- Fekete: a teljes névrajz, kivéve a fokszámokat és mélységszámokat.

- Sötétkék: a fokhálózat és fokszámok, az Ekliptika, a partvonal, a vízrajz (vízfolyások, tókontúrok és felületsraffozásuk), a tengeráramlásrajz, áramlásnyilak és mélységszámok, valamint az országhatárrajz (egy része) és a településkarikák. 
- Világoskék: a tengerfelületek.

- Élénksárga: az országhatárrajz egy része.

- Barna: a lejtốcsíkozásos domborzatábrázolás.

- Élénkvörös: az országhatárrajz egy része.

- Téglavörös: az országhatárrajz egy része.

- Zöld: az országhatárrajz egy része.

\section{1,6 cm-es Felk1- Gönczy-földgömb a marosvásárhelyi Teleki Tékában}

A több helyen - a Déli-sark közelében különösen jelentôs mértékben sérült, állványát vesztett, de a kevésbé sérült részeken elfogadható állapotban levô glóbusz a marosvásárhelyi Teleki Téka (Teleki-Bolyai Könyvtár) gyưjteményében található. A glóbusz elemzó ismertetését Petelei Klára fényképfelvételei nyomán sikerült összeállítani, a közléshez Lázok Klára, a Téka osztályvezetője járult hozzá.

A földgömb egyike a legkorábbi 31,6 cm-es Felkl-Gönczyglóbuszkiadásoknak, mivel Felkı János és Prága szerepel a kolofonban, és talán az elsố is, bár a Budapest (1873. január 1-tôl) és nem Buda és Pest megírást találhatjuk rajta. Azonban korábban már láttuk, hogy a Gönczybibliográfiák 1870-re teszik a Gönczy által a Felklnél kiadott első és egyetlen (!) glóbusz megjelenési idejét. Lehet, hogy már ekkor is „a levegóben volt” a városegyesítés gondolata.

Ehhez a gömbhöz idôben nagyon közel áll egy azonos átmérôjú Hunfalvy-elôzmény, egy 1868 és 1870 közé datálható glóbusz (VGM ID 131) (Márton 2011). Ez gazdagabb, de régiesebb névrajzú földgömb, pl. Gönczy „Behring tenger”-e Hunfalvynál „BERING V. KAMCSITKAI TENG”, vagy az "Aleuti sz”, „Aleuta szigetek” névre hallgat; „Aljaska” helyén „OROSZ AMERIKA”, illetve a „BRITORSZÁGI ÉJSZAKAMERIKA” helyén „BRIT ÉSZAK AMERIKA” megnevezés áll. (Ma: Kamcsatka, Alaszka, Aleutszigetek és Kanada.) Megjegyzendô, hogy a Gönczy-glóbusz kiadásának idejére, 1870-re az „Orosz Amerika”

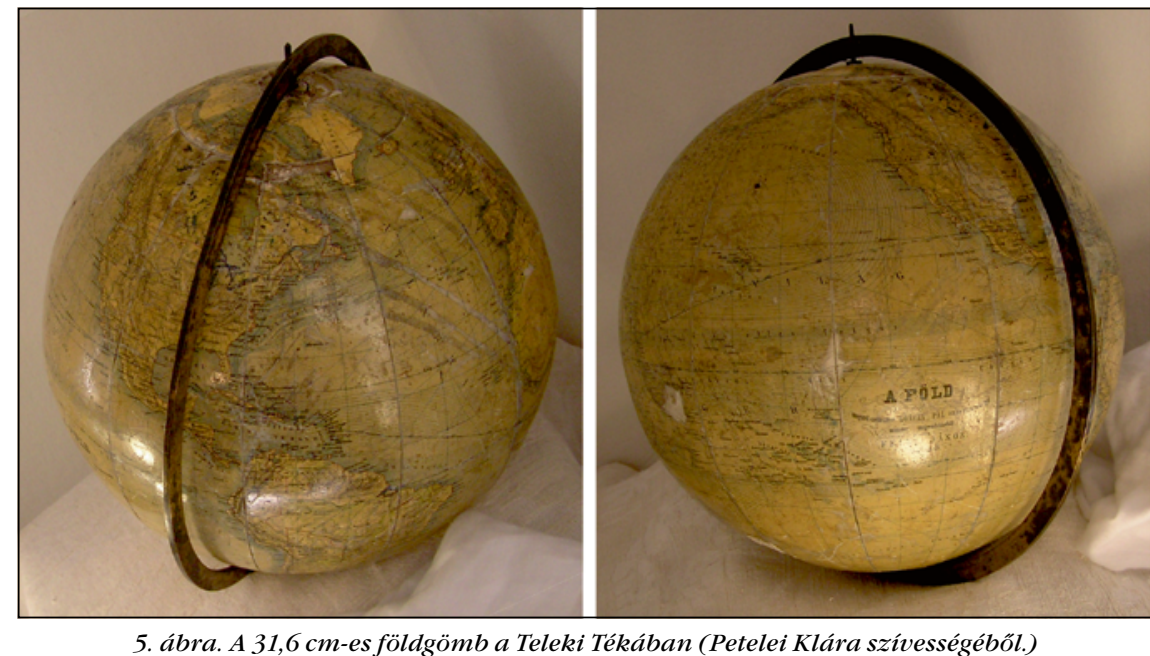

földrajzi név használata politikai okok miatt már elvesztette létjogosultságát, mivel az Egyesült Államok 1867 ben megvásárolta Oroszországtól, és a szerződést az amerikai elnök június 20-án alá is írta. Az „Aljaska” név az orosz „Амяска” átvétele.

Még egy érdekes néveltérésre érdemes felhívni a figyelmet: a Hunfalvy magyarította gömbön szereplő „Aral tó”-val egyezô a marosvásárhelyi, ezzel szemben a Császi-gyújteménybeli glóbuszon „Urál-tó”, míg a VGM ID 100 jelún „Arál-tó”, a VGM ID 105 jelún pedig „Urál tö” szerepel.

$31,6 \mathrm{~cm}$ (12 bécsi hüvelyk) átmérốjû, 1 : 40379000 méretarányú domborzati-politikai földgömb. Egyenlítôi kerülete: 99,25 cm.

Hipszometrikus színezésú (magasságiréteg-szinezésû), lejtôcsíkozásos domborzatrajzú, országhatárbandos, 1870-ben (esetleg 1873-ban?) kiadott glóbusz, párhuzamos vonalfonatokkal jelölt tengeráramlásokkal, áramlásnevekkel és nyilakkal jelölt áramlásirányokkal, hajózási útvonalakkal. Ferrói kezdőmeridián, és innen kelet felé $360^{\circ}$-ig haladva $10^{\circ}$-onként megírt hosszúsági körök, valamint fordított állásban megrajzolt Ekliptika jellemzi. A kolofon: „A FÖLD | magyarul szerkesztette GÖNCZY PÁL a m kir közoktatásügyi | minister megrendeléséból | kiadta | FELKL JÁNOS | PRÁGÁBAN."

A földgömb $30^{\circ}$-os, papírra nyomtatott gömbszegmensek hordozógömbre kasírozásával készült. A $12 \mathrm{db}$ - csonkolt - gömbszegmenst $2 \mathrm{db} 23,5^{\circ}$ pólustávolságú (a sarkkörökig nyúló) pólussapka egészíti ki. A hordozógömb

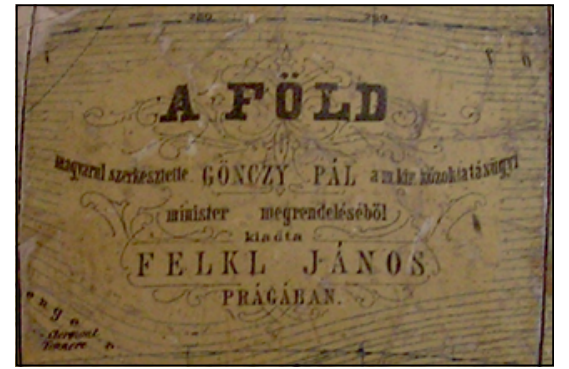

6. ábra. A glóbusz kolofonja (Petelei Klára szívességéböl.)

valószínúsíthetôen favázra rögzített papírmaséból készült, amelynek egyenetlenségeit vékony gipszréteggel simították. Mivel csak a teljes meridiángyúrứje maradt meg, az állványáról az analógiák alapján feltételezhetjük, hogy teljes felszerelésú, naptárkeretes lehetett, hasonló az alább tárgyalt Császi-gyưjiteménybeli glóbuszéhoz (9. ábra).

\section{A glóbusz térképi}

\section{tartalmának jellemzói}

- A vetület: valószínúsíthetốen meridiánokban és Egyenlítôben hossztartó hengervetület („négyzetes hengervetület") transzverzális elhelyezésú változata a $30^{\circ}$-os gömbszegmensek, illetve Postel-féle meridiánban hossztartó síkvetület a 23,5-os pólustávolságú pólussapkák elkészítéséhez.

- Ferrói kezdőmeridián.

- Vékony, folyamatos vonalakkal megrajzolt, $10^{\circ}$-os beosztású, a térítôk és sarkkörök ugyancsak folyamatos vonalú ábrázolásával kiegészített fokhálózat. Az Egyenlítô és a $0^{\circ}$-os (kezdô-) meridián, valamint az Ekliptika kiemelt, ún. létrás ábrázolású. 
- A kontinensek és a jelentôsebb szigetek partvonalán túl a vízrajz a nagyobb folyókat és ezek fôbb mellékfolyóit, valamint a legjelentôsebb tavakat (mélységábrázolás nélkül) tartalmazza.

- A szárazföldi területeken a hipszometrikus ábrázolást fekete színú lejtốcsíkozásos domborzatrajz egészíti ki. A partvonalak mentén rajzolt vízszintes sraffozás emeli ki a szárazföldeket.

- Az országhatárok fekete pontsorral és/vagy mellette húzódó színes határbanddal jelöltek.

- A településábrázolás nem kategorizált (a jel sötétkék üres karika), a megírásban is egységesen normál, kurrens (nagykezdőbetûs) és kurzív (dőlt) írás.

- A névrajz az oktatási célnak megfelelốen a magyar vagy magyaros írásmódot követi (Varsó, Krakko, Bécs, Kairo, Új Orleans stb.). A már említett településmegírásokon túl a névrajzi elemek között szerepel az országok (EGYESÚLT ALLAMOK, BOLIVIA, NAGY BRITANNIA, SPANYOL ORSZ), a tagállamok (Anglia, Skótorsz, KIRÁlYNÉ F., DÉLI ÚJ VALES), a legfontosabb szigetek (Nagy Antillák, Galapagos sz, Aleuti sz, Társaság szig.), félszigetek (Florida, Yucatan), földfokok ( $\mathrm{S}^{\mathrm{z}}$ Vincze f., Jóreménység-f., S. Ferencz-f), a legjelentôsebb hegységek neve (Sziklás hegység, Alleghany hegy, Nagy Khingan, Kárpátok), valamint vízfolyások (Sajna, Viszla, Dnjeper, Don, Volga, Ganges, Brahmaputra, Hoang ho, Császár csat), tavak (Baikal tó) és az óceánok (INDIAI VILÁG TENGER), tengerek (KARIBI TENGER, Korall tenger, DÉLI KINAI TENGER), jelentôsebb tengeröblök (Hudson öble, MEXICÓI ÖBÖL, Sziami öböl, Carpentaria öböl), tengerszorosok (Gibraltari szor., Mozambikuei szoros) nevei, illetve a tengeráramlások (Golf folyása, Perui folyas, Déli ausztraliai folyás) megírása. A fokszámok közül a hosszúsági értékek ( $10^{\circ}$-onként $0^{\circ}$-tól $360^{\circ}$-ig számozva!) az Egyenlítôn, a szélességi értékek a kezdômeridiánon vannak megírva. A névrajzi elemek között nem szerepelnek a kontinensnevek.
- A tengerek területe fehér színú, amelyen vékony sötétkék vonalkötegek mutatják a tengeráramlásokat, az irány (nyíl) megadásával, vízmélységadatok feltüntetésével.

- A nyomási színek száma hét: fekete, sötétkék, világoszöld, okker, vörösbarna, világoskék, téglavörös.

- Fekete: a teljes névrajz, ide értve a kolofont is, valamint az országhatárrajz koronavonalát adó pontsor.

- Sötétkék: a fokhálózat, a partvonal, a vízrajz, településkarikák és a tengerhajózási útvonalak.

- Világoszöld: a hipszometria - a síkvidéki területek (1. szint).

- Okker: a hipszometria - a dombvidéki területek (2. szint).

- Vörösbarna: a hegyrajz - csíkozásos domborzatábrázolás.

- Világoskék: a vízfelületek (tenger, tavak).

- Téglavörös: az országhatárbandok.

Hazánk szúkebb környezetében a következô földrajzi nevekkel találkozhatunk (7. ábra): Viszla, Varsó, Dresd.[en], Borolado = Boroszló (?), Lengyelor, Galic., Lemberg, Krakko, Praga, Bécs, Kárpátok, Dnejszter, AUSTRIA, Budapest, Magyarorsz, Jasszy = Jászvásár, Trieszt, Temesvar, Oláh. orsz, Bukar.[est], Adriai-teng., Belgrad, Serbia, Serai $=$ Serajevo $/$ Sarajevo, Widdin, Duna, TÖRÖ[KORSZ], Adria[napoli] = Edirne $/$ Drinápoly, Szalon[iki]. (A földrajzi nevek elhelyezését meglehetôsen „lazán" kezelték!)

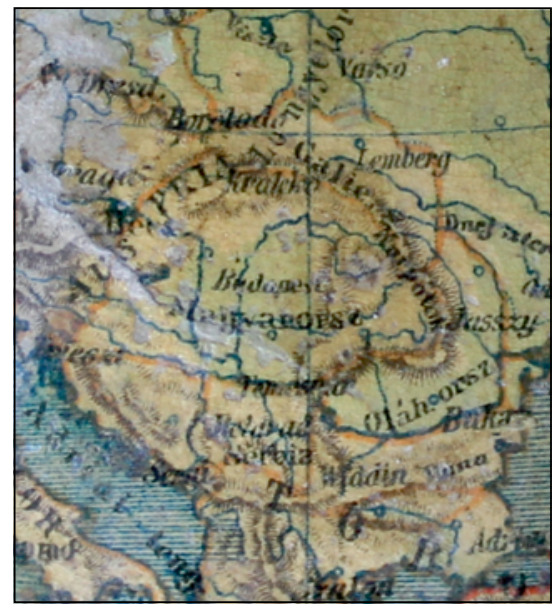

7. ábra. Magyarország és környezete a glóbuszon (Petelei Klára szivességébôl.)

\section{1,6 cm-es Felk1-Gönczy- földgömb Császi Tamás magángyứjteményéból}

A Gönczy magyarította prágai Felkl és a roztoki Felkl és fia által több alkalommal is kiadott $31,6 \mathrm{~cm}$ átmérôjú glóbuszok eddig nem ismert példánya a Császi-gyújtemény darabja. Nem azonos a VGM ID 105 jelzetú földgömbbel, csak „rokona” annak. Az állványzata is teljesen más.

$31,6 \mathrm{~cm}$ (12 bécsi hüvelyk) átmérójû, 1 : 40379000 méretarányú domborzati-politikai földgömb. Egyenlitối kerülete: 99,25 cm.

Hipszometrikus színezésú, lejtôcsíkozásos domborzatrajzú, országhatárbandos, 1897-ben kiadott glóbusz, párhuzamos vonalfonatokkal jelölt tengeráramlásokkal, áramlásnevekkel és nyilakkal jelölt áramlásirányokkal, hajózási útvonalakkal. Ferrói (!) kezdômeridián, és innen kelet felé $360^{\circ}$-ig haladva $10^{\circ}$ onként megírt hosszúsági körök, valamint fordított állásban megrajzolt Ekliptika jellemzi. A kolofon: „A FÖLD | magyarul szerkesztette GÖNCZY PÁL a m kir közoktatásügyí (!) | minister megrendeléséböl | kiadta | FELKL J. ÉS FIA | ROZTOK

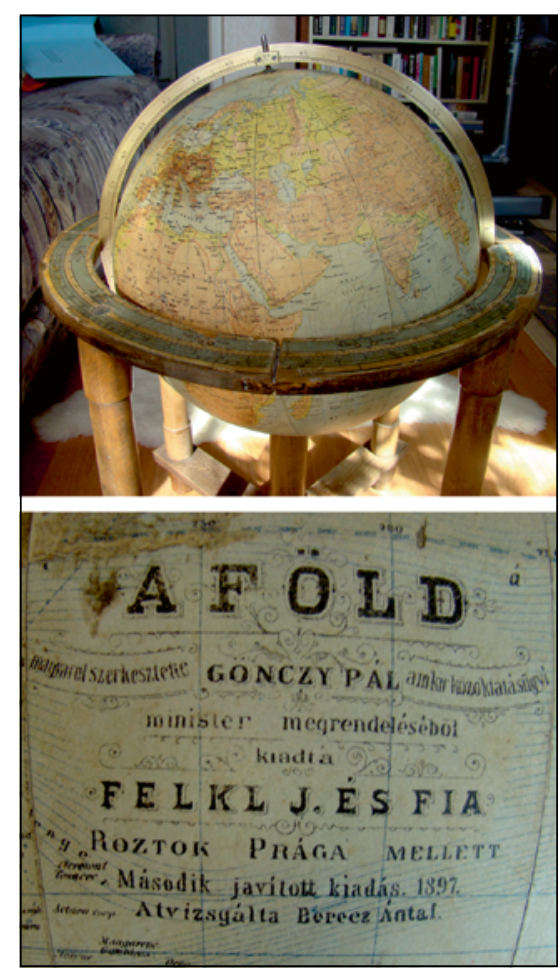

8. ábra. A 31,6 cm-es földgömb a Császigyújteményben (Fotók: Császi Tamás) 
PRÁGA MELLETT | Második javított kiadás. 1897. | Atvizsgálta (!) Berecz Ántal (!).”

\section{A glóbusz térképi tartalmának jellemzói}

- A vetület: valószínúsíthetôen meridiánokban és Egyenlítôben hossztartó hengervetület („négyzetes hengervetület") transzverzális elhelyezésú változata a $30^{\circ}$-os gömbszegmensek, illetve Postel-féle meridiánban hossztartó síkvetület a 23,5-os pólustávolságú pólussapkák elkészítéséhez.

- Ferrói kezdômeridián.

- Vékony, folyamatos vonalakkal megrajzolt, $10^{\circ}$-os beosztású, a térítôk és sarkkörök ugyancsak folyamatos vonalú ábrázolásával kiegészített fokhálózat. Az Egyenlítô és a $0^{\circ}$-os (kezdő-) meridián, valamint az Ekliptika kiemelt, ún. létrás ábrázolású.

- A kontinensek és a jelentôsebb szigetek partvonalán túl a vízrajz a nagyobb folyókat és ezek fóbb mellékfolyóit, valamint a legjelentôsebb tavakat (mélységábrázolás nélkül) tartalmazza.

- A szárazföldi területeken a hipszometrikus ábrázolást fekete színú lejtốcsíkozásos domborzatrajz egészíti ki. A partvonalak mentén rajzolt vízszintes sraffozás emeli ki a szárazföldeket.

- Az országhatárok fekete pontsorral és/vagy mellette húzódó színes határbanddal jelöltek.

- A településábrázolás nem kategorizált (a jel sötétkék üres karika),

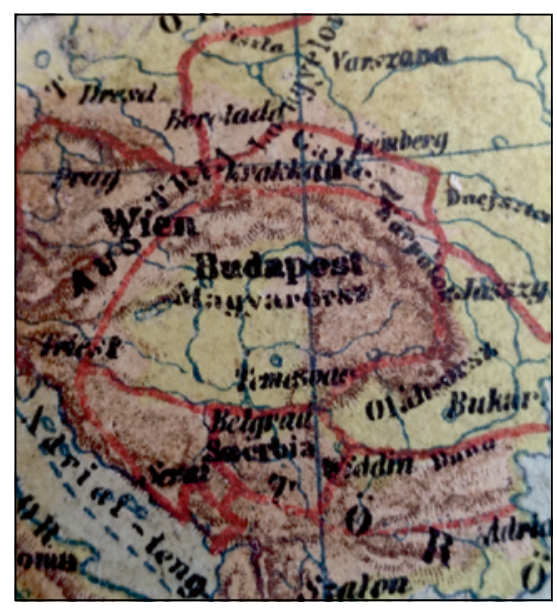

9. ábra. Magyarország és szükebb környezete a glóbuszon (Császi Tamás szivességébôl.) a megírásban a jelentôsebb (fố?) városok kiemeltek (Wien, Budapest, Moszkva, Kairo stb.) félkövér, kurrens és álló, a többi normál, kurrens és kurzív (dôlt) írás.

- A névrajz a deklarált oktatási célnak megfelelően - hiszen „a m kir közoktatásügyí (!) | minister megrendeléséböl" született - többnyire magyar vagy magyaros írásmódot követ, de a hazánk környezetében levô nevek is azt jelzik, hogy a korábbi kiadású a marosvásárhelyi glóbusz neveihez képest eltolódás tapasztalható a német nevek alkalmazása felé: Bécs helyett Wien, Krakkó helyett Krakkau (!), Trieszt helyett Triest stb. Egyetlen üdítô kivétel, hogy Szerbia itt „sz”szel van megírva. A névrajzi elemek között itt sem szerepelnek a kontinensnevek!

- Magyarország környezetében a következô földrajzi nevekkel találkozhatunk (9. ábra): Viszla, Varszava, Dresd.[en], Borolado = Boroszló (?), Lengyelor, Galic., Lemberg, Krakkau, Prag, Wien, Kárpátok, Dnejszter, AUSTRIA, Budapest, Magyarorsz, Jasszy = Jászvásár, Triest, Temesvar, Oláh-orsz, Bukar. [est], Adriai-teng., Belgrad, Szerbia, Serai $=$ Serajevo $/$ Sarajevo, Widdin, Duna, TÖRÖ[KORSZ], Adria[napoli] = Edirne/Drinápoly, Szalon[iki].

- A nevek elhelyezését itt is „lazán” kezelték!

- A nevezetes szélességi körök - az Egyenlítôt kivéve - megnevezve szerepelnek: Északi sarkkör, Ráktérítő, Bak-térítő, Deli sarkkör.

- A fokszámok közül a hosszúsági értékek $\left(10^{\circ}\right.$-onként $0^{\circ}$-tól $360^{\circ}$-ig számozva!) az Egyenlítôn, a szélességi értékek a kezdômeridiánon vannak megírva.

- A nyomási színek száma hét: fekete, sötétkék, világoszöld, okker, vörösbarna, világoskék, téglavörös.

- Fekete: a teljes névrajz, ide értve a kolofont is.

- Sötétkék: a fokhálózat, a partvonal, a vízrajz, a településkarikák és a tengerhajózási útvonalak, valamint a szaggatott vonalú vagy pontozott (ország)határrajz.

- Világoszöld: a hipszometria - a síkvidéki területek (1. szint).
- Okker: a hipszometria - a dombvidéki területek (2. szint).

- Vörösbarna: a hegyrajz - csíkozásos domborzatábrázolás.

- Világoskék: a vízfelületek (tenger, tavak).

- Téglavörös: az országhatárbandok.

\section{Egy nemrég megújult} 47,4 cm-es Felk1-Gönczyglóbusz és a restaurálás meglepetései

A Magyar Földrajzi Múzeum kiállításán szereplő, a Magyar Földrajzi Társaság tulajdonában lévő glóbusz.

$47,4 \mathrm{~cm}$ (18 bécsi hüvelyk) átmérôjjú, 1 : 26919000 méretarányú domborzati-politikai földgömb. Egyenlitối kerülete: $148,87 \mathrm{~cm}$.

Kontinens- és országhatárbandos, lejtôcsíkozásos domborzatrajzú, 1870-ben kiadott földgömb, párhuzamos vonalfonatokkal jelölt tengeráramlás-ábrázolással, áramlásnevekkel, tengermélységadatokkal, valamint „táviró huzal” nyomvonalakkal és kikötôtől kikötőig megírt, sorszámozott hajózási útvonalakkal és távolságmegjelöléssel. Ferrói kezdômeridián és innen kelet felé $360^{\circ}$. ig haladva $10^{\circ}$-onként megírt hosszúsági körök, valamint fordított állásban megrajzolt Ekliptika (!) jellemzik. Közel egykorú kiadású a VGM ID 137 jelú földgömbbel, de az északi pólussapka tartalma és rajzolata alapján ez az újabb. A kolofon: „A | FÖLD | magyarul szerkesztette | Gönczy Pál | a m. kir. közoktatásügyi minister megrendeléséböl (!) | kiadta | FELKL JÁNOS | PRÁGÁBAN | -x- | Köre metszette és nyomatta (!) | H. KUNSCH. | LIPCSÉBEN." (VGM ID 149; Az OSZK kiállításán nem szerepelt!; Plihál könyvében: nincs leírás).

A bemutatott glóbusz kiadásának idôpontját megadja, hogy a Gönczybibliográfiában ez a dátum szerepel. Ezt erôsíti, hogy „a m. kir. közoktatásügyi minister megrendeléséböl" született (azaz gyakorlatilag nem lehet 1869 elôtti, hiszen a törvényt az uralkodó csak 1868. december 15-én hagyta jóvá), és Prágában adták ki (a Felk1 cég a Prága melletti Roztokba tette át székhelyét 1870-ben, tehát nem lehet ennél későbbi). 


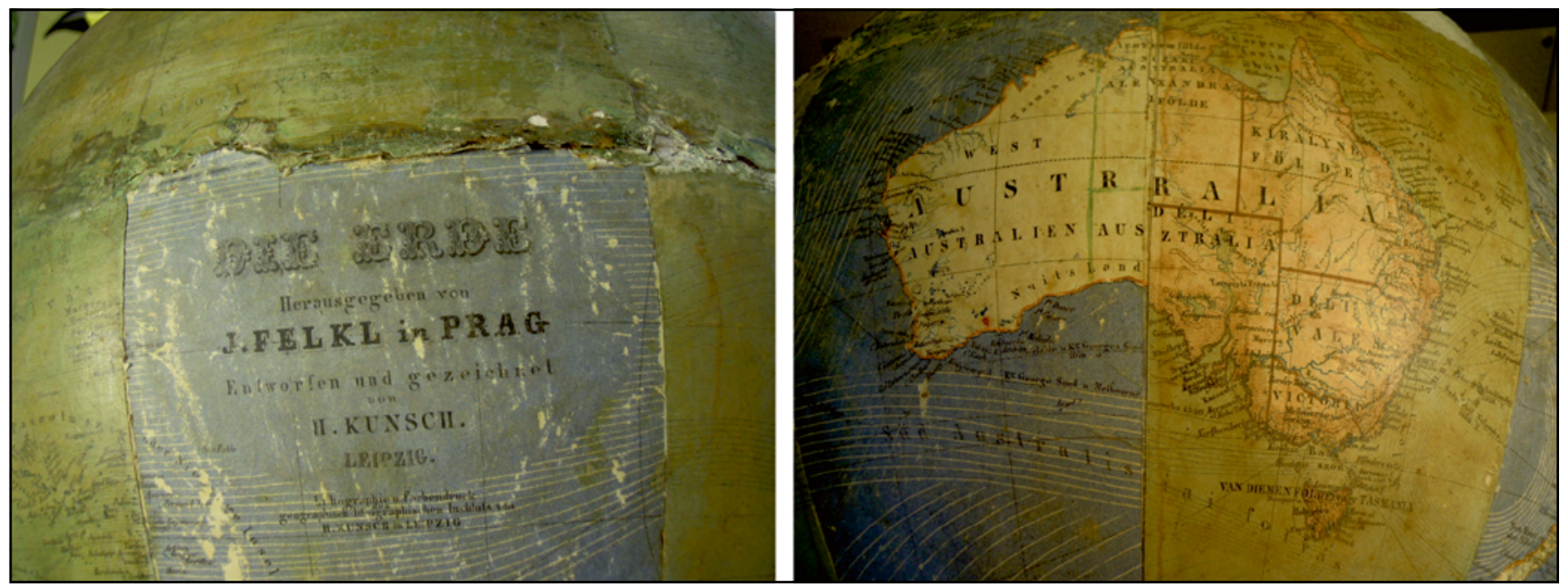

10. ábra. A lefejtett magyar (déli fél) gömbszegmens alól feltûnik a német kolofon (balra). Ausztrália nyugati részén és tôle keletre feltárult az eredeti német kasírozás, míg Ausztrália keleti részén a le nem fejtett magyar nyelvú gömbszegmensrész látszik még (jobbra). (Fotók: Lente Zsuzsanna)

A földgömböt Lente Zsuzsanna restaurálta. A szerencsés kezú múvész praxisában nem az elsố eset, hogy amikor a restaurálás során lefejti a gömbszegmenseket a hordozógömbrôl, alatta egy másik kasírozott gömbkétszögsort talál. Ez történt a Kiepert-glóbusz esetében 2009ben (http://lazarus.elte.hu/hun/ tantort/2009/2009-10-06-kiepertszeged/kiepert.htm), és ahogy az alábbi képek mutatják, ez történt ennek a földgömbnek a restaurálásakor is.

A földgömb $30^{\circ}$-os, papírra nyomtatott gömbszegmensek hordozógömbre kasírozásával készült. A $12 \mathrm{db}$ - sarkokig nyúló - gömbszegmenst $2 \mathrm{db} 23,5^{\circ}$ pólustávolságú (a sarkkörökig nyúló) pólussapka egészíti ki. A hordozógömb valószínúsíthetôen favázra rögzített papírmaséból készült, amelynek egyenetlenségeit vékony gipszréteggel simították.

Az állvány feketére lakkozott fából készült, ún. III. teljes felszerelésú (naptárkeretes, teljes meridiángyúrús), de iránytû́ nélküli állvány. A naptárkeretet három lábra illesztett három kar tartja, de a más kiadásoknál rendszerint megtalálható, az állványlábak között sárgaréz merevítőkkel kifeszített szelencében elhelyezett iránytû amely a glóbusz pontos tájolását teszi lehetôvé -, itt hiányzik.

A nyolcszögú naptárkereten három (fekete, világoskék és sárga) színnel nyomott nyolcosztatú körgyúrún ötfokonként megírt egyfokos fokbeosztás, az év 365 napos beosztása, az állatövek jele és egyszerú képe, a hónapok neve és égtájmegírások találhatók.

A sárgarézból készült teljes meridiángyúrúbe rögzített tengely körül forgatható a glóbusz, amelynek a vízszintessel (illetve a naptárkerettel vagy horizontkörrel) bezárt szöge a tízfokonként megírt meridiángyúrú egyfokos beosztása segítségével pontosan beállítható.

Az Északi-sarknál kettôs órakör van elhelyezve.

Magasság: $107 \mathrm{~cm}$ (a horizontkör/ naptárkeret: $80 \mathrm{~cm}$ ).

\section{A glóbusz térképi tartalmának jellemzôi}

- A vetület: valószínúsíthetôen meridiánokban és Egyenlítőben hossztartó hengervetület („négyzetes hengervetület") transzverzális elhelyezésú változata a $30^{\circ}$-os gömbszegmensek, illetve Postel-féle meridiánban hossztartó síkvetület a 23,5-os pólustávolságú pólussapkák elkészítéséhez.

- Ferrói kezdômeridián.

- A $10^{\circ}$-os beosztású, a térítôk és sarkkörök ábrázolásával kiegészített, a sarkokig terjedô fokhálózat $12 \mathrm{db} 30^{\circ}$-os gömbszegmensre osztott, és 2 pólussapkával egészül ki, amelyek pólustávolsága $23,5^{\circ}$, azaz a sarkkörökig nyúlnak. Az Egyenlítő és a $0^{\circ}$-os (kezdô-) meridián, valamint az Ekliptika kiemelt, ún. létrás ábrázolású, a térítôk és a sarkkörök szaggatott vonallal ábrázoltak.
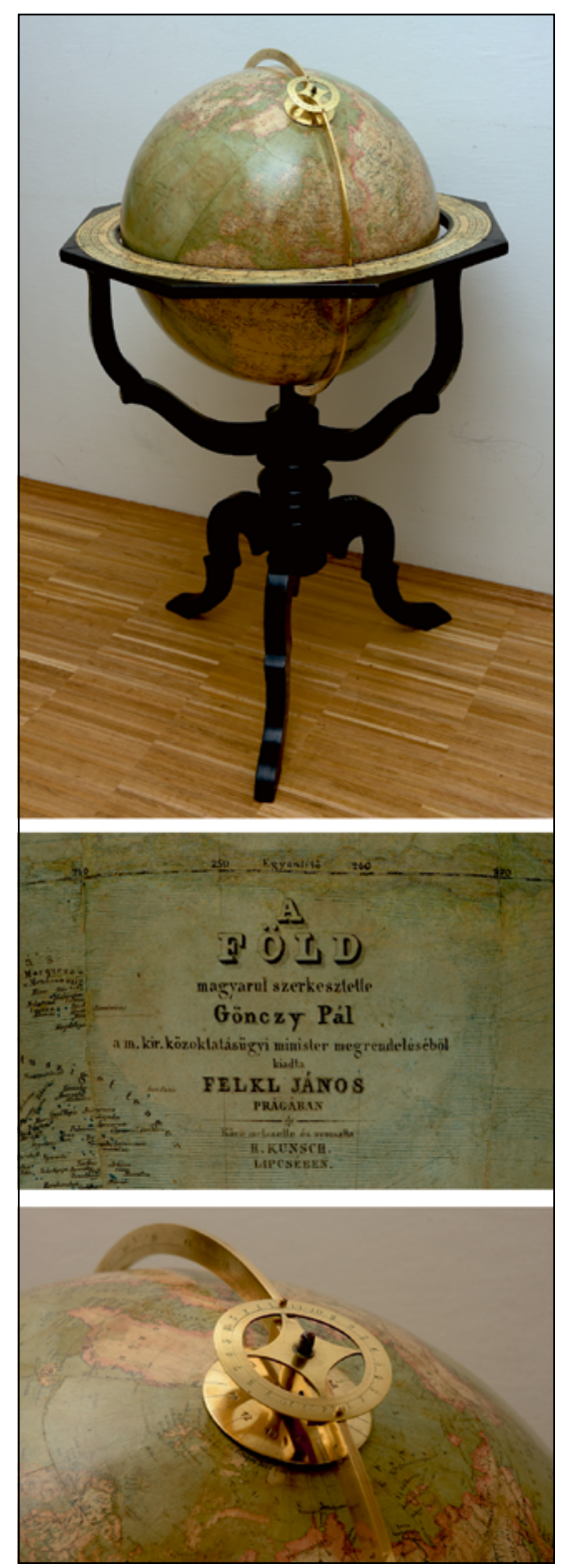

11. ábra. A 47,4 cm-es földgömb a Magyar Földrajzi Múzeumban (Dr. Kubassek János és Puskás Katalin szivességébôl. Fotók: Lente Zsuzsanna) 
- A kontinensek és a jelentôsebb szigetek partvonalán túl a vízrajz a nagyobb folyókat és ezek fóbb mellékfolyóit, valamint a legjelentôsebb tavakat (mélységábrázolás nélkül) tartalmazza.

- A szárazföldi területeken világosokker felületi színezés és barna lejtốcsíkozásos domborzatábrázolás található.

- Az országhatárok pontsorral és/ vagy mellette húzódó színes határbanddal jelöltek.

- A településábrázolás kategorizált (kétféle jelet: karika ponttal a közepén és üres karika, valamint várat: csillag, közepén üres körrel, különböztet meg). A megírásban is három kategória szerepel: álló félkövér verzál (csupa nagybetûs) írás, pl.: BERLIN, VARSÓ, BÉCS; álló félkövér kurrens írás, pl.: Pest, Debrecen, Szeged; dôlt normál írás, pl.: Widdin és Temesvár (az utóbbi várjellel).

- A névrajz az oktatási célnak megfelelően magyar. A már említett településmegírásokon túl a névrajzi elemek között szerepel az országok, a tagállamok, a legfontosabb szigetek, a földfokok, a legjelentősebb hegységek neve, valamint a vízfolyások, a tavak és az óceánok, a tengerek, a jelentôsebb tengeröblök, a tengerszorosok nevei, illetve a tengeráramlások és a hajózási útvonalak megírásai a távolságadatokkal. Az Egyenlítő, a térítôk, a sarkkörök és a sarkok megnevezése is megtalálható. A fokszámok közül a hosszúsági értékek ( $10^{\circ}$-onként $0^{\circ}$-tól $360^{\circ}$-ig számozva!) az Egyenlítőn, a szélességi értékek a kezdőmeridiánon vannak megírva. A névrajzi elemek között nem szerepelnek a kontinensnevek.

- A tengerek területe élénk középkék színú, amelyen vékony fekete vonalkötegek mutatják a tengeráramlásokat, az irány (nyíl) és sebesség megadásával! Vízmélységadatok feltüntetése.
- A nyomási színek száma nyolc: fekete, okker, barna, középkék, téglavörös, vörös (narancsba hajló), sárga és zöld.

- Fekete: a fokhálózat, a partvonal, a vízrajz és a tengerhajózási útvonalak, valamint az összes névrajzi elem, ide értve a kolofont is.

- Okker: a szárazföldi területek (alapszín).

- Barna: a csíkozásos domborzatábrázolás.

- Középkék: a vízfelületek (tenger és tavak), valamint a határbandok.

- Téglavörös: a (kontinens) határbandok.

- Vörös (narancsba hajló): a (kontinens)határbandok.

- Sárga: a határbandok.

- Zöld: a (kontinens)határbandok.

\section{Köszönetnyilvánítás}

Ezúton mondunk köszönetet az érdi Magyar Földrajzi Múzeumban dr. Kubassek János igazgatónak és Puskás Katalin gyújteménykezelő restaurátornak; a zalaegerszegi Göcseji Múzeumban Megyeri Anna történész-fốmuzeológusnak és munkatársának, Dömötör Andreának; a novai Plánder Ferenc Gyưjtemény kezelőjének Horváth Nikolettnek és fotósának Simon Balázsnak; a marosvásárhelyi Teleki Téka munkatársainak Lázok Klárának és Petelei Klárának; Császi Tamás magángyứjtônek; valamint Lente Zsuzsanna restaurátornak önzetlen és pótolhatatlan segítségükért. Nélkülük ez a tanulmány nem készülhetett volna el.

Cikksorozatunk következô részében „új”, utóbb felfedezett SchotteGönczy-földgömbökkel foglalkozunk. Bemutatunk „elérhetetlen”, aukciókon, hirdetéseken feltûnt Gönczyglóbuszokat is.

\section{Irodalom}

Márton Mátyás 2010a. Hunfalvy János és eddig ismeretlen glóbuszai. I. rész Geodézia és Kartográfia 62. évf., 5. szám, pp. 22-29.

Márton Mátyás 2010b. Hunfalvy János és eddig ismeretlen glóbuszai. II. rész Geodézia és Kartográfia 62. évf., 6. szám, pp. 12-16.

Márton Mátyás 2011. Új Hunfalvy-Felkl földgömb.

Geodézia és Kartográfia 63. évf., 2. szám, pp. 10-11.

MTA Alm. 1892. Magyar Tud. Akadémiai Almanach Polgári és Csillagászati Naptárral MDCCCXCII-re.

Kiadja a Magyar Tud. Akadémia, Budapest, 1892, p. 216

A tagok munkálatai: Gönczy Pál pp. 136-138.

Plihál Katalin 2016. Nyomtatott magyar földés éggömbök 1840-1990 Zrínyi Kiadó, Budapest, p. 232

Szabó Virág 2010. Tengeri területek térképi magyar névanyagának fejlôdéstörténeti vizsgálata XIX. és XX. századi földgömbök alapján

Diplomamunka, ELTE Térképtudományi és Geoinformatikai Tanszék

Szinnyei József 1894. Magyar írók élete és munkái, 3. kötet. Gönczy Pál pp. 13601367. Hornyánszky Viktor, Budapest, p. 1582

http://lazarus.elte.hu/hun/tantort/2009/2009. 10-06-kiepert-szeged/kiepert.htm (Utolsô elérés: 2021. augusztus 01.)

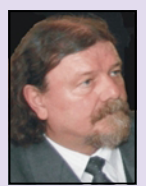

Dr. Márton Mátyás professor emeritus

ELTE Térképtudományi és Geoinformatikai Intézet matyi@map.elte.hu

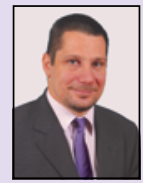

Dr. Toronyi

Bence

adjunktus

Budapesti Múszaki és Gazdaságtudományi Egyetem, Építőmérnöki Kar, Általános és Felsôgeodézia Tanszék toronyi.bence@emk.bme.hu 